PEREIRA, Marta Carolina Gimenez; BOFF, Salete Oro; BRITTO, Emilio Elias Melo de. Internacionalização das indicações geográficas e a sua influência no Mercosul. Revista Eletrônica Direito e Política, Programa de Pós-Graduação Stricto Sensu em Ciência Jurídica da UNIVALI, Itajaí, v.16, n.3, $3^{\circ}$ quadrimestre de 2021. Disponível em: www.univali.br/direitoepolitica - ISSN 1980-7791.

\title{
INTERNACIONALIZAÇÃO DAS INDICAÇÕES GEOGRÁFICAS E A SUA INFLUÊNCIA NO MERCOSUL
}

\author{
INTERNATIONALIZATION OF GEOGRAPHICAL INDICATIONS AND THEIR
}

INFLUENCE ON MERCOSUR

Marta Carolina Gimenez Pereira1

Salete Oro Boff ${ }^{2}$

Emilio Elias Melo de Britto ${ }^{3}$

\section{RESUMO}

As Indicações Geográficas - IGs certificam a procedência e os padrões técnicos de produtos e serviços, com características distintas de outros. A distinção pode ser resultante de fatores naturais (solo, clima, vegetação etc) e/ou humanos (como o saber fazer que passa de geração em geração). Sobre este tema, pretende-se demonstrar o protagonismo das Indicações Geográficas e o processo de internacionalização no MERCOSUL, especialmente tomando em conta o novo Acordo para a Proteção Mútua das Indicações Geográficas Originárias nos Territórios dos Estados-partes do Mercado Comum do Sul - MERCOSUL, o qual reconhece que as IGs são fundamentais no desenvolvimento das economia dos Países-parte e estabelece critérios para termos de uso comum e regras gerais para a

\footnotetext{
1 Doutora em Direito pelo Instituto de Investigaciones Jurídicas da Universidad Nacional Autónoma de Mexico (IIJ UNAM). Pós-Doutora em Direito pela Faculdade Meridional (IMED), Brasil. Pós-Doutora em Direito pela MICHR de la Universidad "Mediterranea" de Reggio Calabria, Italia. Professora Pesquisadora Visitante do Programa de Graduação em Direito da Universidade Federal da Bahia (UFBA). Líder do Grupo de Pesquisa Propriedade Intelectual e Novas Tecnologias (PINTEC) na UFBA, membro do Grupo de Estudos em Desenvolvimento, Inovação e Propriedade Intelectual (GEDIPI) na IMED e do Seminario Permanente en Propiedad Intelectual (SEPEPI) do IIJ UNAM, México. E-mail: magipe@hotmail.com.

2 Doutora em Direito-UNISINOS. Estágio Pós-Doutoral-UFSC. Coordenadora e Professora do Professor do Programa de Pós-Graduação em Direito da Faculdade Meridional, de Passo Fundo IMED - Mestrado em Direito. Professora da UFFS. Linha de Pesquisa "Dimensões jurídico-políticas da tecnologia e da Inovação". Grupo de Pesquisa CNPq "Direitos, Novas Tecnologias e Desenvolvimento". Grupo de estudo GEDIPI. Membro do Seminario Permanente en Propiedad Intelectual (SEPEPI) do IIJ UNAM, México. https://orcid.org/0000-0002-7159-187. E-mail: salete.oro.boff@gmail.com

3 Mestrando na Universidade Federal da Bahia (UFBA). Pós-Graduado em Direito Processual Civil. Possui graduação em Direito pela Universidade Salvador - UNIPACS (2013). Membro do Grupo de Pesquisa Propriedade Intelectual e Novas Tecnologias (PINTEC). Email: emiliobritto.adv@gmail.com
} 
PEREIRA, Marta Carolina Gimenez; BOFF, Salete Oro; BRITTO, Emilio Elias Melo de. Internacionalização das indicações geográficas e a sua influência no Mercosul. Revista Eletrônica Direito e Política, Programa de Pós-Graduação Stricto Sensu em Ciência Jurídica da UNIVALI, Itajaí, v.16, n.3, $3^{\circ}$ quadrimestre de 2021. Disponível em: www.univali.br/direitoepolitica - ISSN 1980-7791.

obtenção de reconhecimento e proteção jurídica. O método utilizado é o dedutivo e a técnica de pesquisa bibliográfica.

PALAVRAS-ChAVE: Indicações Geográficas, MERCOSUL, desenvolvimento, internacionalização.

\section{ABSTRACT}

Geographical Indications - Gls certify the origin and technical standards of products and services, with characteristics that are distinct from others. The distinction can be the result of natural factors (soil, climate, vegetation, etc.) and/or human factors (such as the know-how that passes from generation to generation). On this topic, it is intended to demonstrate the protagonism of Geographical Indications and the internationalization process in MERCOSUR, especially taking into account the new Agreement for the Mutual Protection of Geographical Indications Originating in the Territories of States Parties to the Southern Common Market - MERCOSUR, which recognizes that the Gls are fundamental in the development of the economies of the member countries and establishes criteria for terms of common use and general rules for obtaining recognition and legal protection. The method used is the deductive and bibliographic research technique.

KEYWORDS: Geographical Indications, MERCOSUR, development, internationalization.

\section{INTRODUÇÃO}

A sociedade pós-moderna vem apresentado índices de desenvolvimento e, consequentemente, de inovação elevados. A tecnologia está cada vez mais presente no cotidiano das pessoas e esse fenômeno não é local, atingindo todo o planeta. Em cada parte do mundo, seja em menor ou maior escala, os programas de pesquisa e desenvolvimento estão emergindo e criando novas tecnologias e uma das indústrias mais pujantes é a agroalimentar.

O desenvolvimento tecnológico, aliado à crescente competitividade existente entre as empresas, tem criado um campo perfeito para o surgimento de novos tipos de produtos alimentícios. Estes, em sua maioria geneticamente modificados, os quais provocam incertezas nos consumidores, quanto à sua qualidade e real procedência. 
PEREIRA, Marta Carolina Gimenez; BOFF, Salete Oro; BRITTO, Emilio Elias Melo de. Internacionalização das indicações geográficas e a sua influência no Mercosul. Revista Eletrônica Direito e Política, Programa de Pós-Graduação Stricto Sensu em Ciência Jurídica da UNIVALI, Itajaí, v.16, n.3, $3^{\circ}$ quadrimestre de 2021. Disponível em: www.univali.br/direitoepolitica - ISSN 1980-7791.

Dessa maneira, a segurança alimentar tem se tornado uma questão básica na sociedade. Os consumidores buscam alimentos que tenham uma qualidade certificada com níveis de segurança e higiene elevados e que respeitem altos padrões técnicos.

É nesse contexto que emergem as Indicações Geográficas como instituto certificador de qualidade, de procedência e de padrões técnicos de produtos e serviços que são respeitados há gerações.

Indicação Geográfica de acordo com a legislação nacional brasileira, é um produto ou serviço, que possui características únicas, se comparado aos outros afins, já que, em seu modo de produção, existem particularidades que levam em consideração fatores naturais (solo, clima, vegetação etc) e humanos (como o saber fazer que passa de geração em geração, dentro de uma determinada comunidade, por exemplo).

No Brasil, de acordo a Lei no 9.279/96, existem duas subespécies de Indicações Geográficas. Uma, denominada Indicação de Procedência, se define como "o nome geográfico de país, cidade, região ou localidade de seu território, que se tenha tornado conhecido como centro de extração, produção ou fabricação de determinado produto ou de prestação de determinado serviço" (art. 177, Lei 9.279). A outra, chamada denominação de origem, que se define como "o nome geográfico de país, cidade, região ou localidade de seu território, que designe produto ou serviço, cujas qualidades ou características se devam exclusiva ou essencialmente ao meio geográfico, incluídos fatores naturais e humanos" (art. 178, Lei 9.279).

Este trabalho pretende demonstrar o protagonismo que as Indicações Geográficas têm adquirido, nas últimas décadas e como tem sido o seu processo de internacionalização. Busca-se explicar o momento histórico em que isso ocorreu e os referenciais teóricos que baseiam esse novo olhar para este instituto tão tradicional e local. Além do mais, visa compreender como tem sido esse processo no Bloco Económico ao qual o Brasil faz parte, o MERCOSUL. 
PEREIRA, Marta Carolina Gimenez; BOFF, Salete Oro; BRITTO, Emilio Elias Melo de. Internacionalização das indicações geográficas e a sua influência no Mercosul. Revista Eletrônica Direito e Política, Programa de Pós-Graduação Stricto Sensu em Ciência Jurídica da UNIVALI, Itajaí, v.16, n.3, $3^{\circ}$ quadrimestre de 2021. Disponível em: www.univali.br/direitoepolitica - ISSN 1980-7791.

Para tanto, será demonstrado o seu desenvolvimento histórico, desde a origem, em tempos bíblicos, até a sua fase de internacionalização propriamente dita, através de acordos multilaterais de comércio.

Em seguida, o objetivo é estudar a mudança de paradigma em relação ao que se entende por desenvolvimento econômico, em especial ao rural, e como, a partir dos anos 90, as incertezas provocadas pelo momento histórico pelo qual a sociedade passou a viver, impactaram no instituto da Indicação Geográfica.

Nessa esteira, a intenção é compreender como a Escola Francesa da Economia da Qualidade Alimentar colaborou no processo da internacionalização das Indicações Geográficas e entender como foi e tem sido o processo de internacionalização das Indicações Geográficas no MERCOSUL, considerando como o novo Acordo para a Proteção Mútua das Indicações Geográficas Originárias nos Territórios dos Estados Partes do Mercado Comum do Sul pode impactar nos futuros acordos de comércio.

\section{CONTEXTUALIZAÇÃo HISTÓRICA DAS INDICAÇÕES GEOGRÁFICAS} (IG's)

O conceito de Indicação Geográfica foi, ao longo da história, desenvolvido e aperfeiçoado pelos próprios comerciantes e produtores, que, desde os tempos bíblicos, verificavam qualidades em seus produtos, que poderiam ser relacionados à sua origem. Foi na prática que os produtores e comerciantes verificaram que existia, de fato, uma relação entre o que era produzido e o meio geográfico onde ocorria a produção. Em meio à realização das atividades dos produtores e comerciantes se verificou a existência de um vínculo essencial de qualidade, reputação etc., dos produtos e/ou serviços que poderiam ser atribuídos à região de origem; um vínculo que os transformava em um produto único ${ }^{4}$.

${ }^{4}$ REIS L. L. M. Indicação Geográfica no Brasil: determinantes, limites e possibilidades, Salvador, 2015, 270 f, Tese (Doutorado) - Universidade Federal da Bahia. Instituto de Geociências, 2015, p. 32. 
PEREIRA, Marta Carolina Gimenez; BOFF, Salete Oro; BRITTO, Emilio Elias Melo de. Internacionalização das indicações geográficas e a sua influência no Mercosul. Revista Eletrônica Direito e Política, Programa de Pós-Graduação Stricto Sensu em Ciência Jurídica da UNIVALI, Itajaí, v.16, n.3, $3^{\circ}$ quadrimestre de 2021. Disponível em: www.univali.br/direitoepolitica - ISSN 1980-7791.

Como dito, já existiam, no texto da bíblia, em seu Antigo Testamento, referências a produtos que tinham qualidades que se relacionavam com o meio geográfico onde eram produzidos ${ }^{5}$. As passagens bíblicas são vastas e reveladoras: "Voltarão os que habitam debaixo da sua sombra; serão vivificados como o trigo, e florescerão como a vide; a sua memória será como o vinho do Líbano" 6 . "O rei Salomão fez para si uma carruagem de madeira do Líbano"7. Pelos exemplos relacionados, pode-se perceber as referências, já em tempos bíblicos, a uma determinada indicação geográfica, para destacar a boa qualidade ou boa reputação de um produto.

Na Antiguidade Clássica, foram verificados produtos que se vinculavam a uma região, como, por exemplo, os vinhos de Corintos e Rodes, por volta só século IV a.C. ${ }^{8}$. No Império Romano, também havia vinhos que era exaltados por sua origem, mas foram os mármores de Carrada que ficaram mais famosos, além das ostras de Brindisi ${ }^{9}$, sem esquecer dos vinhos de Alba, Falernum e Sorrento ${ }^{10}$.

Logo, percebe-se que existe a necessidade de se atribuir aos produtos de origem intelectual um status de propriedade ${ }^{11}$. Há registros que, na Mesopotâmia, no século XX a. C., já existiam nos produtos sinais distintivos, que possibilitavam a sua diferenciação, ou seja, surgiu essa necessidade com o comércio ${ }^{12}$.

\footnotetext{
5 BRUCH, K. L. Signos Distintivos de Origem: Entre o Velho e o Novo Mundo Vitivinícola, 2011, 277f, Tese de Doutorado em Direito para obtenção do título de Doutor em Direito no Programa de Pós-Graduação em Direito da Universidade Federal do Rio Grande do Sul e o título de Doutor em Direito na Université Rennes I, 2011, p. 42 e ss.

${ }^{6}$ BÍBLIA, Oséias, 14,7. Disponível em www.bibliaonline.com.br.

7 BÍBLIA, Oséias, 14,7. Cânticos, 3, 9. Disponível em www.bibliaonline.com.br.

8 BARROS, C. E. C. Manual de Propriedade Intelectual. Aracaju: Evocati, 2007.

9 PORTO, P.C.R. Indicações Geográficas: a proteção adequada deste instituto visando o interesse público nacional. Monografia (Pós-graduação em Direito). Faculdade de Direito, Universidade Federal do Rio de Janeiro, Rio de Janeiro, 2007, p. 17;

ALMEIDA, A.F.R. IG, indicação de proveniência e denominação de origem: os nomes geográficos na propriedade industrial. In: A. M. LEITÃO et al, Direito industrial. vol. I, Coimbra: Almedina, 2001, p. 5-77.

10 ALMEIDA, A. F. R. A Autonomia Jurídica da Denominação de Origem, Almedina, 2010.

11 VARELLA, M. D. Propriedade intelectual de setores emergentes, Atlas, São Paulo, 1996.

12 CARVALHO, N.T. P. A estrutura dos sistemas de patentes e de marcas - passado, presente e futuro, Lumem Juris, Rio de Janeiro, 2009 p. 471.
} 
PEREIRA, Marta Carolina Gimenez; BOFF, Salete Oro; BRITTO, Emilio Elias Melo de. Internacionalização das indicações geográficas e a sua influência no Mercosul. Revista Eletrônica Direito e Política, Programa de Pós-Graduação Stricto Sensu em Ciência Jurídica da UNIVALI, Itajaí, v.16, n.3, $3^{\circ}$ quadrimestre de 2021. Disponível em: www.univali.br/direitoepolitica - ISSN 1980-7791.

Os signos que distinguiam a origem dos produtos tinham, segundo Nuno Tomaz Pires de Carvalho ${ }^{13}$, uma função básica e específica: de informar a quem pertencia determinado produto. Entretanto, foi na Idade Média que sugiram os primeiros estudos e regulamentações, mesmo que incipientes, sobre Indicações Geográficas $^{14}$.

O objetivo dos signos era de proteger e responsabilizar um fabricante que produzisse o produto em desconformidade com as regras da corporação ${ }^{15}$. Nessa esteira, somente no final da Idade Média, com a intensificação do comércio e das feiras internacionais, que os signos de origem que identificavam os produtos e que indicavam, sobretudo, qualidade, passaram a ganhar mais destaque. Desta forma, tais produtos passam a ter mais valor e, por via de consequência, passaram a ser mais bem remunerados ${ }^{16}$.

Foi nesse momento da história que as Cidades, então, descobriam que um signo indicando a procedência de um produto era um "bom negócio" e começaram a requerer ao Estado, na figura do Monarca, o privilégio de uso exclusivo dos seus signos, consolidando-se, assim, o monopólio e os privilégios das corporações ${ }^{17}$. De acordo com Dominique Denis ${ }^{18}$, na França surgiu o conceito de Indicação Geográfica, quando houve tentativa de se diferenciar o vinho da Borgonha dos demais.

13 CARVALHO, N.T. P. A estrutura dos sistemas de patentes e de marcas - passado, presente e futuro, Lumem Juris, Rio de Janeiro, 2009 p. 471-473.

14 REIS, L. L. M. Indicação Geográfica no Brasil: determinantes, limites e possibilidades, Salvador, 2015, 270 f, Tese (Doutorado) - Universidade Federal da Bahia. Instituto de Geociências, 2015, p. 32.

15 LAGO GIL, R. Las marcas colectivasy las marcas de garantia, 2 ed.,Navarra: Civitas, 2006, p. 36.

16 BRUCH, K. L.Signos Distintivos de Origem: Entre o Velho e o Novo Mundo Vitivinícola, 2011, 277f, Tese de Doutorado em Direito para obtenção do título de Doutor em Direito no Programa de Pós-Graduação em Direito da Universidade Federal do Rio Grande do Sul e o título de Doutor em Direito na Université Rennes I, 2011, p. 49-57.

17 CARVALHO, N. T. P., op. cit., pp. 561-584; L. BRUCH, op. cit., pp. 49-57

18 DENIS, D. Appellation d'origine et indication de provenance. Paris: Dalloz, 1995 
PEREIRA, Marta Carolina Gimenez; BOFF, Salete Oro; BRITTO, Emilio Elias Melo de. Internacionalização das indicações geográficas e a sua influência no Mercosul. Revista Eletrônica Direito e Política, Programa de Pós-Graduação Stricto Sensu em Ciência Jurídica da UNIVALI, Itajaí, v.16, n.3, $3^{\circ}$ quadrimestre de 2021. Disponível em: www.univali.br/direitoepolitica - ISSN 1980-7791.

Com o fim da Idade Média e início da Idade Moderna, a lógica de monopólios e privilégios é quebrada pela liberdade de comercialização. Na França, o Décret d'Allarde, de 2-17 de março de 1791, em seu artigo 7, anuncia tal mudança ${ }^{19}$ :

Il sera libre à toute personne de faire tel négoce ou d'exercer telle profession, art ou métier qu'elle trouvera bon; mais elle sera tenue de se pourvoir auparavant d'une patente, d'en acquitter le prix suivant les taux ci-après déterminés et de se conformer aux règlements de police qui sont ou pourront être faits.

Em Portugal, a primeira demarcação de uma área geográfica ocorreu com o Alvará Régio de 10 de setembro de 1756, que criava a Companhia Geral das Vinhas do Alto Douro, feita com 335 marcos de pedra e que fora expedido pelo Marques de Pombal. A finalidade era identificar a procedência do vinho do Douro e, com isso, manter a sua reputação. Dizia o referido alvará:

Lavradores de cima do Douro, e Homens Bons da Cidade do "Porto, nellas ennunciados, fizeraõ, e ordenarão com meu Real consentimento, para formarem huma Companhia, que sustentando competentemente a cultura das vinhas do Alvo Douro, conserve ao mesmo tempo as producçoens delias na sua pureza natural, em benefício do comercio Nacional, e Estrangeiro, e da saude pureza meus Vassallos, sem alguma despeza da minha Fazenda, antes com benefício della, e do bem commum dos meus Reynos.

Em nível internacional, as Indicações Geográficas foram ganhando destaque. Na Europa que esse processo mais se intensificou, principalmente a partir do século $\mathrm{XIX}^{20}$. O governo francês foi quem primeiro regulamentou as denominações de origem, em $1^{0}$ de agosto 1905 . A lei tinha a finalidade de conter a crise ocasionada

19 FRISON-ROCHE, M. A.; PAYET, M. S. Droit de la concurrence. Paris: Dalloz, 2006, p. 1; CERQUEIRA, J. Tratado da propriedade intelectual, Vol. I, Revista Forense, Rio de Janeiro, 1946, p. 341; BRUCH, K. L. Signos Distintivos de Origem: Entre o Velho e o Novo Mundo Vitivinícola, 2011, 277f, Tese de Doutorado em Direito para obtenção do título de Doutor em Direito no Programa de Pós-Graduação em Direito da Universidade Federal do Rio Grande do Sul e o título de Doutor em Direito na Université Rennes I, 2011, p. 58.

20 BUGALLO, B. La protección jurídica de las indicaciones geograficas en los países del Mercosur. In: Anuario de Derecho Comercial, Tomo 9, Montevideo: Fundacion de Cultura Universitaria, 2001, p. 83. 
PEREIRA, Marta Carolina Gimenez; BOFF, Salete Oro; BRITTO, Emilio Elias Melo de. Internacionalização das indicações geográficas e a sua influência no Mercosul. Revista Eletrônica Direito e Política, Programa de Pós-Graduação Stricto Sensu em Ciência Jurídica da UNIVALI, Itajaí, v.16, n.3, $3^{\circ}$ quadrimestre de 2021. Disponível em: www.univali.br/direitoepolitica - ISSN 1980-7791.

pelo inseto Phylloxera, que desencadeou uma profunda recessão no setor vitivinícola, através da repressão a concorrência desleal ${ }^{21}$.

Salienta-se que, no final da Idade Moderna, os Estados Nacionais, de uma maneira geral, passaram a legislar sobre signos de origem, com o objetivo, também, de proteger os seus produtos, mas, infelizmente, essas normas não foram suficientes para impedir as falsificações e atos de concorrência desleal. Naquele ponto, nem mesmo acordos bilaterais foram eficazes ${ }^{22}$.

Desta forma, fez-se necessário uma regulamentação de âmbito internacional. A primeira regulamentação multilateral no tocante as Indicações Geográficas foi a Convenção da União de Paris (CUP), firmada em 1883. A Convenção não conceitua propriamente 0 instituto, se limita a proibir as falsas indicações de procedência (Arts. 9 e 10). O Brasil, por sua vez, foi signatário do tratado e o ratificou através do Decreto no $75.547 / 75$.

Em 1891, foi celebrado o Acordo de Madri, ratificado pelo Brasil pelo Decreto no 19.056/1929. Esse documento também não definia o que seria uma indicação geográfica, mas repetiu a repressão das falsas indicações de procedência, que já contava na CUP, e somou a ela a punição às indicações enganosas. Entretanto, com as lacunas ainda existentes, fez-se necessário firmar o Acordo e o Protocolo de Lisboa, que conferiu às Indicações Geográficas uma maior proteção. Segundo 0 art. $20, \S 1^{\circ}$ :

Entende-se por apelação de origem, no sentido do presente Acordo, a denominação geográfica de um país, região ou localidade que serve para designar um produto dele originário cuja qualidade ou caracteres são devidos exclusiva ou essencialmente ao meio geográfico, incluindo os fatores naturais e os fatores humanos

\footnotetext{
21 VIDAL, M. Historie de la vigne et des vins dans le monde. Bordeaux: Féret, 2001.

22 REIS, L. L. M. Indicação Geográfica no Brasil: determinantes, limites e possibilidades, Salvador, 2015, 270 f, Tese (Doutorado) - Universidade Federal da Bahia. Instituto de Geociências, 2015, p. 37.
} 
PEREIRA, Marta Carolina Gimenez; BOFF, Salete Oro; BRITTO, Emilio Elias Melo de. Internacionalização das indicações geográficas e a sua influência no Mercosul. Revista Eletrônica Direito e Política, Programa de Pós-Graduação Stricto Sensu em Ciência Jurídica da UNIVALI, Itajaí, v.16, n.3, $3^{\circ}$ quadrimestre de 2021. Disponível em: www.univali.br/direitoepolitica - ISSN 1980-7791.

Como se pode perceber, o acordo consagrou a vinculação entre os fatores naturais e humanos para a produção de um produto singular.

Por fim, o Acordo ADPIC/TRIPS (Trade-Related Aspects of Intellectual Property Rights), selado em 1995 e avalizado pela Organização Mundial do Comércio (OMC). A criação, por meio de sua inclusão na Rodada do Uruguai, deveu-se principalmente ao entendimento de que haveria um aumento do comércio internacional, com uma maior proteção dos direitos de Propriedade Intelectual ${ }^{23}$.

O acordo versa sobre as proteções mínimas que devem ser concedidas aos direitos de Propriedade Intelectual, nos quais estão incluídas as Indicações Geográficas. O referido acordo assim conceitua o instituto das Indicações Geográficas, em sua parte II, seção 3, art. 22-1:

As indicações servem para identificar um produto como sendo originário do território de um membro, ou da região ou localidade deste território, nos casos em que uma qualidade, reputação, ou outra característica determinada do produto pode ser atribuída essencialmente a esta origem geográfica.

O conceito é propositadamente amplo, possuindo, assim, o claro objetivo de harmonizar os diversos conceitos adotados pelos países signatários. Neste mesmo sentido são as palavras de Livia Liberato de Matos Reis"24: "Inspirada na Denominação de Origem do Acordo de Lisboa, a definição supracitada é ampla, porquanto abarca a Denominação de Origem, a Indicação de Procedência, e as Denominações Tradicionais com origem geográfica, fixadas pelo Direito da Comunidade Europeia. A abrangência universal das IG, definidas no âmbito do Acordo ADPIC, na tentativa de harmonizar as diferenças nacionais dos conceitos de indicações geográficas entre os países signatários, representa sua fragilidade. A conceituação vaga deliberada no Acordo suscita divergências no âmbito da OMC,

23 REIS, L. L. M. Indicação Geográfica no Brasil: determinantes, limites e possibilidades, Salvador, 2015, 270 f, Tese (Doutorado) - Universidade Federal da Bahia. Instituto de Geociências, 2015, p. 43.

24 REIS, L. L. M. Indicação Geográfica no Brasil: determinantes, limites e possibilidades, Salvador, 2015, 270 f, Tese (Doutorado) - Universidade Federal da Bahia. Instituto de Geociências, 2015, p. 45. 
PEREIRA, Marta Carolina Gimenez; BOFF, Salete Oro; BRITTO, Emilio Elias Melo de. Internacionalização das indicações geográficas e a sua influência no Mercosul. Revista Eletrônica Direito e Política, Programa de Pós-Graduação Stricto Sensu em Ciência Jurídica da UNIVALI, Itajaí, v.16, n.3, $3^{\circ}$ quadrimestre de 2021. Disponível em: www.univali.br/direitoepolitica - ISSN 1980-7791.

cuja preocupação prática com a proteção das IG tem sido restringida à concorrência desleal."

Como se percebe, naquele contexto, as Indicações Geográficas tinham a premência de internacionalização, haja vista ter se tornado um importante ativo no comércio internacional. Além do mais, diversos outros fatores influenciaram na sua internacionalização, o que será analisado nos tópicos a seguir.

\section{DESENVOLVIMENTO RURAL E INTERLOCUÇÕES COM AS INDICAÇÕES GEOGRÁFICAS}

Antes de adentrar no recorte específico deste trabalho, faz-se necessário analisar as mudanças no modelo de desenvolvimento rural. De acordo com Zander Navarro ${ }^{25}$, dois foram os momentos históricos que impactaram na noção de "desenvolvimento", o que, por consequência, ocasionou impacto na compreensão de desenvolvimento rural.

O primeiro deles ocorreu após a Segunda Guerra Mundial, no contexto da Guerra Fria, e se estendeu até a década de 70. Havia, naquele período, uma polarização, gerando, assim, um "crescimento econômico da época, que materializou um padrão civilizatório dominante". Assim, houve uma revolução no modo de vida e nos comportamentos sociais, bem como a possibilidade do desenvolvimento, que alimentou esperanças e estimulou iniciativas diversas em todas as sociedades ${ }^{26}$. $\mathrm{O}$ desenvolvimento econômico impactou, obviamente, no desenvolvimento rural, uma vez que a maior parte do mundo, mesmo as nações mais civilizadas, ainda tinha no campo um dos principais setores econômicos.

Salienta-se que houve uma significativa mudança do modo de se compreender o que seria agricultura. Foi o que, na época, se chamou de "revolução verde". Essa

25 NAVARRO, Z. Desenvolvimento rural no Brasil - os limites do passado e os caminhos do futuro. Estudos Avançados, vol.15, no 43, set./dez 2011.

26 NAVARRO, Z. Desenvolvimento rural no Brasil - os limites do passado e os caminhos do futuro. Estudos Avançados, vol.15, no 43, set./dez 2011, p. 83. 
PEREIRA, Marta Carolina Gimenez; BOFF, Salete Oro; BRITTO, Emilio Elias Melo de. Internacionalização das indicações geográficas e a sua influência no Mercosul. Revista Eletrônica Direito e Política, Programa de Pós-Graduação Stricto Sensu em Ciência Jurídica da UNIVALI, Itajaí, v.16, n.3, $3^{\circ}$ quadrimestre de 2021. Disponível em: www.univali.br/direitoepolitica - ISSN 1980-7791.

nova concepção "rompeu radicalmente com o passado, por integrar fortemente as famílias rurais a novas formas de racionalidade produtiva, mercantilizando gradualmente a vida social" 27 .

O período em que a agricultura se "modernizou" (de 1950-1975), que houve a implementação de tecnologia, havendo aumento na produtividade e na produção, mas a agricultura passou a se subordinar aos modos de vida e consumo urbanos. Apesar do contexto bipolar de guerra fria, Zander Navarro ${ }^{28}$ explica que esse contexto de desenvolvimento é semelhante tanto na porção capitalista, quanto na porção socialista do globo. Ele analisa, dizendo: "Já no conjunto dos países então alinhados com a órbita socialista as propostas não eram em sua essência diferentes no tocante aos formatos tecnológicos, modificando-se tão somente os aparatos institucionais, as formas de propriedade e a redistribuição dos eventuais resultados produtivos. As poucas exceções a este ideário produtivista que dominou aquele período (tanto à direita como à esquerda, saliente-se) também redundaram em experiências malsucedidas."

No final dos anos 70, esse modelo de "desenvolvimento" chegou ao seu fim. O motivo foi o fato de que havia muita expectativa no seu sucesso, mas os resultados revelaram que a população, principalmente a rural, não saiu da pobreza. Além disso, houve o "estancamento da fase econômica expansionista do pós-guerra (refreado já em meados dos anos 70)" e, posteriormente, o ideal conservador que "gradualmente se instalou na virada daquela década"29.

O segundo momento identificado iniciou-se a partir dos anos 90. Ao contrário do primeiro período, o segundo momento é marcado pela sua impossibilidade, sensação gerada por um sentimento de incertezas, especialmente com relação ao

27 NAVARRO, Z. Desenvolvimento rural no Brasil - os limites do passado e os caminhos do futuro. Estudos Avançados, vol.15, no 43, set./dez 2011, p. 84.

28 NAVARRO, Z. Desenvolvimento rural no Brasil - os limites do passado e os caminhos do futuro. Estudos Avançados, vol.15, no 43, set./dez 2011.

29 NAVARRO, Z. Desenvolvimento rural no Brasil - os limites do passado e os caminhos do futuro.

Estudos Avançados, vol.15, no 43, set./dez 2011. 
PEREIRA, Marta Carolina Gimenez; BOFF, Salete Oro; BRITTO, Emilio Elias Melo de. Internacionalização das indicações geográficas e a sua influência no Mercosul. Revista Eletrônica Direito e Política, Programa de Pós-Graduação Stricto Sensu em Ciência Jurídica da UNIVALI, Itajaí, v.16, n.3, $3^{\circ}$ quadrimestre de 2021. Disponível em: www.univali.br/direitoepolitica - ISSN 1980-7791.

futuro $^{30}$. Passa-se a conviver com a "globalização", que modifica radicalmente os modelos sociais e econômicos, provocando, desta maneira, uma sensação de incerteza que o mundo ainda não havia experimentado. É, portanto, um "quadro de mudanças rápidas, profundas e inéditas" ${ }^{31}$.

No tocante ao fenômeno da globalização, apesar de existirem importantes doutrinadores, como Manuel Castells ${ }^{32}$ e David Harvey ${ }^{33}$, que afirmam que esse fenômeno afeta a autonomia e, também, a identidade dos territórios e nações, existem outros que afirmam exatamente o oposto. Veltz ${ }^{34}$, que afirma que "conceber a globalização como extensão universal de um capitalismo homogêneo é um absurdo" (tradução nossa). Para aquele doutrinador, a ideia não seria exterminar as fronteiras entre os territórios e estabelecer um padrão, mas sim dominar a diversidade existente entre eles.

Desta forma, a globalização, segundo Denis Maillat ${ }^{35}$, fortalece o que se chama de "local" e o insere no "global", valorizando, assim, as produções territoriais. "Os exemplos das ditas regiões "ganhadoras" atestam a importância dos fenômenos de territorialização como elementos determinantes da competitividade dos sistemas territoriais de produção"36. Convergem nessa mesma posição JeanClaude Perrin ${ }^{37}$ e Allen J. Scott ${ }^{38}$. Mesmo que a globalização não desenvolva o modelo econômico de arquipélagos, que se constitui, basicamente, em um reagrupamento espacial de atividades, em que os grandes centros urbanos

\footnotetext{
30 NAVARRO, Z. Desenvolvimento rural no Brasil - os limites do passado e os caminhos do futuro. Estudos Avançados, vol.15, no 43, set./dez 2011.

31 NAVARRO, Z. Desenvolvimento rural no Brasil - os limites do passado e os caminhos do futuro. Estudos Avançados, vol.15, no 43, set./dez 2011, p. 87.

32 CASTELLS, M. The information economy and the new international division of labour, In: CARNOY, M. et al. (ed.). The New Global Economy in the Information Age. PA: University Park, 1993.

33 HARVEY, D. The Condition of Postmodernity. Oxford: Blackwell, 1989.

34 VELTZ, P. Mondialisation, villes et territoires : l'économie d'archipel, Presses Universitaires de France, Paris, 2005, p. 124-150.

35 MAILLAT, D. Globalização, meio inovador e sistemas territoriais de produção. Revista Internacional de Desenvolvimento Local, vol. 3, N. 4, p. 9-16, mar. 2002.

36 MAILLAT, D. Globalização, meio inovador e sistemas territoriais de produção. Revista Internacional de Desenvolvimento Local, vol. 3, N. 4, p. 9-16, mar. 2002, p. 9.

37 PERRIN, J. C. La reconversion du Bassin d'Alès, CER, Aixen-Provence, 1983.

38 SCOTT, A. High Technology and Territorial Developpment. The Rise of the Orange County Complex.

Urban Geography, n. 7, p. 3-45, 1986.
} 
PEREIRA, Marta Carolina Gimenez; BOFF, Salete Oro; BRITTO, Emilio Elias Melo de. Internacionalização das indicações geográficas e a sua influência no Mercosul. Revista Eletrônica Direito e Política, Programa de Pós-Graduação Stricto Sensu em Ciência Jurídica da UNIVALI, Itajaí, v.16, n.3, $3^{\circ}$ quadrimestre de 2021. Disponível em: www.univali.br/direitoepolitica - ISSN 1980-7791.

formam uma rede global econômica independente, trazendo sérias consequências aos sistemas territoriais, marginalizando-os ${ }^{39}$.

Logo, o modelo econômico atribuído à globalização "está associado ao desenvolvimento do pós-fordismo e àquele das tecnologias de informação, que engendram uma organização produtiva mais flexível"40. Esse modelo reagrupa a produção de uma forma que, em um mesmo lugar, possa haver várias funções de produção e não apenas uma (como de "fornecimento de recursos locais préexistentes", por exemplo), o que leva a uma autonomia ${ }^{41}(. .$.$) "cada região rivaliza-$ se com todas as outras no plano dos custos, da gama de produtos e de sua qualidade" 42 .

As preocupações com as mudanças climáticas também passam a ser objeto de debate, principalmente com o surgimento do Protocolo de Kyoto. Nesse passo, a compreensão de desenvolvimento passa a ser analisada também sob a perspectiva ambiental, haja vista as formas predatórias do uso da terra ${ }^{43}$. Assim, a relação entre desenvolvimento e meio ambiente passa a gerar contornos que irão impactar demasiadamente no pensamento da sociedade como um todo. É o que explica Navarro ${ }^{44}$ ao argumentar a necessidade "gerar novos contornos $(\ldots)$, gerando outras formas de gestão dos recursos naturais, provavelmente impositivas. Bastaria associar este fato à extraordinária revolução tecnológica em curso na agricultura $(\ldots)^{\prime \prime}$.

Como se pode observar, houve uma mudança radical na compreensão e no modo de se conceber a agricultura, relacionada com a mudança na perspectiva do que se entende por desenvolvimento, em especial, o desenvolvimento rural. Após a

39 MAILLAT, D. Globalização, meio inovador e sistemas territoriais de produção. Revista Internacional de Desenvolvimento Local, vol. 3, N. 4, p. 9-16, mar. 2002, p. 9.

40 MAILLAT, D. Globalização, meio inovador e sistemas territoriais de produção. Revista Internacional de Desenvolvimento Local, vol. 3, N. 4, p. 9-16, mar. 2002, p. 10.

41 MAILLAT, D. Globalização, meio inovador e sistemas territoriais de produção. Revista Internacional de Desenvolvimento Local, vol. 3, N. 4, p. 9-16, mar. 2002, p. 10.

42 OCDE, Economies locales et globalisation, Paris, 1995, p. 10.

43 NAVARRO, Z. Desenvolvimento rural no Brasil - os limites do passado e os caminhos do futuro. Estudos Avançados, vol.15, no 43, set./dez 2011.

44 NAVARRO, Z. Desenvolvimento rural no Brasil - os limites do passado e os caminhos do futuro.

Estudos Avançados, vol.15, no 43, set./dez 2011, p. 85. 
PEREIRA, Marta Carolina Gimenez; BOFF, Salete Oro; BRITTO, Emilio Elias Melo de. Internacionalização das indicações geográficas e a sua influência no Mercosul. Revista Eletrônica Direito e Política, Programa de Pós-Graduação Stricto Sensu em Ciência Jurídica da UNIVALI, Itajaí, v.16, n.3, $3^{\circ}$ quadrimestre de 2021. Disponível em: www.univali.br/direitoepolitica - ISSN 1980-7791.

Segunda Grande Guerra, ao mesmo tempo dos acordos multilaterais em Propriedade Intelectual, surgiu a "Revolução Verde", que modernizou e mercantilizou a agricultura. Posteriormente, sob um novo contexto de incertezas, em especial, as mudanças climáticas, emerge um novo modelo, no qual se inserem as Indicações Geográficas.

O modelo de mercado produtivista, baseado em commodities agrícolas, herdado dos "anos dourados", de intensa modernização, não mais atendiam aos anseios sociais, que visam, hoje, a um desenvolvimento voltado para questões como aquelas de cunho ambiental. Existem análises, entretanto, que demonstram que o modelo tradicional de produção ainda não foi totalmente superado, mas que existem "perspectivas mais otimistas, que sugerem que, mais do que evidências de crise do modelo tradicional, algumas regiões já estariam diante de uma espécie de pós-produtivismo, revelado por processos de modelo endógeno e territorializados agenciados por atores mais locais". ${ }^{45}$

Com dito, o desenvolvimento rural baseado do produtivismo é usualmente relacionado às cadeias globais de commodities, que são "controladas por empresas transnacionais livres de qualquer vínculo com as localidades de mesmo com os Estados-Nacionais ${ }^{46}$. A sua característica principal é, portanto, a "standardização de produtos, processos e pessoas" ${ }^{47}$, o contrário do que acontece com o modelo de desenvolvimento concebido nos anos 90.

Os produtos advindos desse modelo produtivista são, em sua maioria, produtos agropecuários, que, por suas próprias características, necessitam de normas técnicas que meçam a sua qualidade sanitária.

45 NIEDERLE, P. A. Delimitando as fronteiras entre mercados convencionais e alternativos para a agricultura familiar. Revista de Extensão Rural, DEAER/PPGExR - CCR - UFSM, Ano XVI, n 18, Jul/2009, p. 6-7.

46 NIEDERLE, P. A. Delimitando as fronteiras entre mercados convencionais e alternativos para a agricultura familiar. Revista de Extensão Rural, DEAER/PPGEXR - CCR - UFSM, Ano XVI, no 18, Jul/2009, p. 7.

47 BUSCH, L., The Moral economy of grades and standards. Journal of Rural Studies, n. 16, 2000, p. 273-283. 
PEREIRA, Marta Carolina Gimenez; BOFF, Salete Oro; BRITTO, Emilio Elias Melo de. Internacionalização das indicações geográficas e a sua influência no Mercosul. Revista Eletrônica Direito e Política, Programa de Pós-Graduação Stricto Sensu em Ciência Jurídica da UNIVALI, Itajaí, v.16, n.3, $3^{\circ}$ quadrimestre de 2021. Disponível em: www.univali.br/direitoepolitica - ISSN 1980-7791.

Somado a isso, o novo modelo de desenvolvimento provoca incertezas no tocante a questões ambientais e, consequentemente, a procedência dos alimentos, ainda mais frente à existência de crises alimentares (doenças) e transgênicos. Logo, a alternativa que resta aos consumidores é a procura por alimentos que tenha a sua qualidade e procedência regularmente atestados. É exatamente nesse contexto que emerge o interesse na internacionalização das Indicações Geográficas, que será analisada no próximo tópico.

\section{INTERNACIONALIZAÇÃO DAS INDICAÇÕES GEOGRÁFICAS}

Após a compreensão das importantes premissas apontadas, quais sejam, as novas necessidades de consumo frente às incertezas provocadas principalmente pela globalização e mudanças climáticas; e o modelo de mosaico de organização econômica da produção, partiremos para uma segunda etapa deste trabalho, que é o estudo do embasamento teórico da internacionalização das Indicações Geográficas.

As primeiras questões que devem ser provocadas são: por que internacionalizar justamente as Indicações Geográficas? Por que envolver as Indicações Geográficas em negócios internacionais?

Para começar a responder a esses questionamentos, deve-se, de logo, ter em mente que a sociedade contemporânea tem provocado mudanças significativas também no mundo empresarial. Isso se deve à globalização e à relativização das fronteiras físicas através da internet, que ocasionam uma maior proximidade entre os povos e nações. A tecnologia tem, desta forma, encurtado as distâncias, inclusive culturais, entre as pessoas no planeta.

É a "sociedade em rede", que Manuel Castells ${ }^{48}$ definiu como um "conjunto de nós interconectados". São as exatas palavras do mestre: "A sociedade em rede, em

48 CASTELLS, M. A sociedade em rede, 10. ed. São Paulo: Paz e Terra, 2007. 
PEREIRA, Marta Carolina Gimenez; BOFF, Salete Oro; BRITTO, Emilio Elias Melo de. Internacionalização das indicações geográficas e a sua influência no Mercosul. Revista Eletrônica Direito e Política, Programa de Pós-Graduação Stricto Sensu em Ciência Jurídica da UNIVALI, Itajaí, v.16, n.3, $3^{\circ}$ quadrimestre de 2021. Disponível em: www.univali.br/direitoepolitica - ISSN 1980-7791.

termos simples, é uma estrutura social baseada em redes operadas por tecnologias de comunicação e informação fundamentadas na microelectrónica e em redes digitais de computadores que geram, processam e distribuem informação a partir de conhecimento acumulado nos nós dessas redes. A rede é a estrutura formal (vide Monge e Contractor, 2004). É um sistema de nós interligados. E os nós são, em linguagem formal, os pontos onde a curva se intersecta a si própria. As redes são estruturas abertas que evoluem acrescentando ou removendo nós de acordo com as mudanças necessárias dos programas que conseguem atingir os objectivos de performance para a rede. Estes programas são decididos socialmente fora da rede mas a partir do momento em que são inscritos na lógica da rede, a rede vai seguir eficientemente essas instruções, acrescentando, apagando e reconfigurando, até que um novo programa substitua ou modifique os códigos que comandam esse sistema operativo"49.

A "hiper-interconectividade" entre as pessoas possibilita que empresas de todos os tamanhos, de pequeno, médio e grande porte, possam estar em pé de igualdade na competição dos mercados. Empresas que antes só exerciam influência em sua região geográfica, hoje podem vender para todo o mundo, graças à internet. Esse novo paradigma mundial foi nomeado por Robert D. Hisrich, Michael P. Peter e Dean

A. Shepherd ${ }^{50}$ como "Economia Global Hipercompetitiva".

Diante dessa mudança estrutural na sociedade contemporânea, nada mais natural que a transposição dos negócios empresariais para adquirir novos mercados fora de suas fronteiras nacionais. Há, assim, um acirramento competitivo internacional entre as empresas, já que não há mais as barreiras que anteriormente se impunham.

Somado a esse fato, há a elevação da exigência dos mercados e dos consumidores para adquirir produtos que tenham uma origem certificada. Isso porque, como observado no ponto anterior, o clima de incertezas surgido na década de 90 tem

49 CASTELLS, M. A sociedade em rede, 10. ed. São Paulo: Paz e Terra, 2007, p. 20.

50 HISRICH, P. A.; PETERS, M. P.; SHEPHERD, D. A. Empreendedorismo. 5. ed. Porto Alegre: Bookman, 2004. 
PEREIRA, Marta Carolina Gimenez; BOFF, Salete Oro; BRITTO, Emilio Elias Melo de. Internacionalização das indicações geográficas e a sua influência no Mercosul. Revista Eletrônica Direito e Política, Programa de Pós-Graduação Stricto Sensu em Ciência Jurídica da UNIVALI, Itajaí, v.16, n.3, $3^{\circ}$ quadrimestre de 2021. Disponível em: www.univali.br/direitoepolitica - ISSN 1980-7791.

ocasionado uma maior procura por produtos e serviços que inspirem confiança e, por assim dizer, com certificação de origem. Logo, a qualidade e segurança alimentar têm alcançado altos níveis de procura:

O mercado de certificações na agricultura tem crescido devido à necessidade de garantir a qualidade dos alimentos a um consumidor cada vez mais exigente e atento às questões de segurança alimentar ocorridas como a doença da vaca louca, a gripe aviária, a produção de alimentos transgênicos, a gordura trans e outros eventos" ${ }^{\prime 51}$.

O desenvolvimento tecnológico, também fator propulsor dessa nova onda de incertezas, cria produtos, através da biotecnologia, diversificando, assim, a gama de produtos disponíveis no mercado. Por outro lado, "multiplicam as possibilidades de erros, oportunismos, problemas sanitários e de higiene. O consumidor está preocupado com questões de higiene, nutrição, saúde e efeitos de longo prazo sobre seu físico e seu organismo"52.

A certificação dos produtos agropecuários se enquadra perfeitamente nesse contexto de indefinições provocadas, dentre outros fatores, pela evolução tecnológica, globalização e mudanças climáticas, porque garante a procedência do produto. Nassar (1999) citado por Natália de Freitas Lazzarotto ${ }^{53}$ explica certificação com maestria, ao afirmar que é uma "definição de atributos de um produto, processo ou serviço e a garantia de que eles se enquadram em normas pré-estabelecidas".

É neste momento que se insere o referencial teórico da Escola Francesa da Economia da Qualidade Agroalimentar, que alia conceitos de economia e ciências

51 STAUDT, SATO, PITHAN E SILVA, VARELA, CHALITA. Processo de Certificação De Qualidade Para Produtos Agroalimentares: o selo produto. Informações Econômicas, v.39, n.3, São Paulo, mar. 2009, p. 69.

52 STAUDT, SATO, PITHAN E SILVA, VARELA, CHALITA. Processo de Certificação De Qualidade Para Produtos Agroalimentares: o selo produto. Informações Econômicas, v.39, n.3, São Paulo, mar. 2009, p. 69.

53 NASSAR, A. M. Certificação no agronegócio. Estudo temático. IX Seminário Internacional PENSA de Agribusiness, Águas de São Pedro, 1999.

LAZZAROTTO, N. F. Estudos sobre o mercado de certificações de qualidade em alimentos no Brasil. Seminários de Administração, 5., FEA/USP, São Paulo, 2001, p. 4 ss. 
PEREIRA, Marta Carolina Gimenez; BOFF, Salete Oro; BRITTO, Emilio Elias Melo de. Internacionalização das indicações geográficas e a sua influência no Mercosul. Revista Eletrônica Direito e Política, Programa de Pós-Graduação Stricto Sensu em Ciência Jurídica da UNIVALI, Itajaí, v.16, n.3, $3^{\circ}$ quadrimestre de 2021. Disponível em: www.univali.br/direitoepolitica - ISSN 1980-7791.

sociais, abordando a qualidade como construção social, e não partir de uma abordagem econômico-tecnológica ${ }^{54}$.

Sob essa perspectiva, podem ser aplicadas duas teorias. A primeira, a Teoria da Economia dos Contratos, que busca reduzir assimetrias no tocante às informações e regras que precisam ser cumpridas. A segunda é a Teoria das Convenções, que compreende que os baixos preços provocados pelo desenvolvimento tradicional, produtivista, não mais atraem os consumidores, que estão agora mais preocupados com questões sociais e ambientais, bem como a que atuação de agentes sociais que visam estabelecer controle de qualidade e desenvolvimento ${ }^{55}$.

Desta maneira, o referencial teórico da qualidade alimentar busca "minimizar os riscos e criar mecanismos de prevenção, através do envolvimento de cada elo da cadeia produtiva, da distribuição e de agentes reguladores"56. Tal teoria converge com o modelo econômico de mosaico, que reagrupa a produção de uma forma que em um mesmo lugar possa ter várias funções de produção e não apenas uma, como ocorria com o modelo econômico de arquipélago.

Logo, as empresas que aderem a um sistema de certificação passam a ter mais receptividade no mercado, já que estabelecem confiança junto ao consumidor, inserindo-se as indicações geográficas nesse contexto.

Com base nas teorias econômicas supracitadas e relacionadas ao processo de globalização, torna-se premente o estudo da história da inserção das Indicações Geográficas no mercado internacional. Sob a premissa da valorização da territorialidade, inserindo o local no global, este trabalho se debruça sobre o recorte epistemológico da análise do MERCOSUL.

\footnotetext{
54 SATO. G.S.; BRITO, P. R. B. A Relevância da Economia da Qualidade Agroalimentar no Contexto Atual, 2007, em http://www.iea.sp.gov.br/out/TerTexto.php?codTexto=8944.

55 EYMARD-DUVERNAY, F. La négociation de la qualité. Économie rurale, $n^{\circ} 217$, La qualité dans l'agro-alimentaire, 1993, p. 12 ss.

56 STAUDT, SATO, PITHAN E SILVA, VARELA, CHALITA. Processo de Certificação De Qualidade Para Produtos Agroalimentares: o selo produto. Informações Econômicas, v.39, n.3, São Paulo, mar. 2009 , p. 69.
} 
PEREIRA, Marta Carolina Gimenez; BOFF, Salete Oro; BRITTO, Emilio Elias Melo de. Internacionalização das indicações geográficas e a sua influência no Mercosul. Revista Eletrônica Direito e Política, Programa de Pós-Graduação Stricto Sensu em Ciência Jurídica da UNIVALI, Itajaí, v.16, n.3, $3^{\circ}$ quadrimestre de 2021. Disponível em: www.univali.br/direitoepolitica - ISSN 1980-7791.

\section{ACORDOS, TRATADOS E CONVENÇÕES À INTERNACIONALIZAÇÃO DAS IGS NO MERCOSUL}

Até este ponto, foi demonstrada a importância do estudo das Indicações Geográficas em uma perspectiva internacional. Elas estão nas localidades em que se inserem e em espaços globais. Com o MERCOSUL, união aduaneira com o fim de formar um mercado comum, não foi diferente. O espírito mundial de internacionalizar os direitos de Propriedade Intelectual - dentre eles, as Indicações Geográficas -, iniciado na Convenção da União de Paris em 1883, não morreu e, ao contrário, permanece vivo e pujante.

O tratado de Assunção foi assinado em 26 de março de 1991, no qual a República Argentina, a República Federativa do Brasil, a República do Paraguai e a República Oriental do Uruguai se comprometeram, em seu art. 10, a constituir um Mercado Comum, que tem entre os seus principais objetivos: "A livre circulação de bens, serviços e fatores produtivos entre os países, através, entre outros, da eliminação dos direitos alfandegários e restrições não tarifárias à circulação de mercadorias e de qualquer outra medida de efeito equivalente. A coordenação de políticas macroeconômicas e setoriais entre os Estados Partes - de comércio exterior, agrícola, industrial, fiscal, monetária, cambial e de capitais, de outras que se acordem -, a fim de assegurar condições adequadas de concorrência entre os Estados Partes."

A Propriedade Intelectual, como ativo econômico/comercial, pode ser abarcado pelo princípio da livre circulação de mercadorias e pelas políticas macroeconômicas e setoriais que assegurarão a livre concorrência entre os Estados Membros do MERCOSUL.

Denis Borges Barbosa57 corrobora essa constatação, ao afirmar que: "Insta entender que não há integração completa de mercados se não houver integração

57 BARBOSA, D. Propriedade Intelectual no âmbito do Mercosul, 2004. Disponível em http://www.denisbarbosa.addr.com/paginas/200/internacional.html. Acesso agosto 2021. 
PEREIRA, Marta Carolina Gimenez; BOFF, Salete Oro; BRITTO, Emilio Elias Melo de. Internacionalização das indicações geográficas e a sua influência no Mercosul. Revista Eletrônica Direito e Política, Programa de Pós-Graduação Stricto Sensu em Ciência Jurídica da UNIVALI, Itajaí, v.16, n.3, $3^{\circ}$ quadrimestre de 2021. Disponível em: www.univali.br/direitoepolitica - ISSN 1980-7791.

dos sistemas de PI, ou seja, se os titulares de marcas, patentes etc., puderem segregar os mercados singulares pela barreira de seu direito." Segundo o autor, "se um bloco econômico objetiva a livre circulação de bens, esses bens englobam os bens de PI".

Além do mais, esse bloco, que nasceu oficialmente no início dos anos 90, não escapa de sofrer os reflexos da globalização ${ }^{58}$. De acordo com Paulo Brasil Dill Soares ${ }^{59}$, foi também a partir da década de 90 que os países do, até então, recémcriado bloco, começaram a intercambiar políticas públicas voltadas ao desenvolvimento rural.

Vale destacar que a Propriedade Intelectual é temática discutida na Comissão de Propriedade Intelectual, do Subgrupo de Trabalho no 7 (Política Industrial e Tecnológica), de acordo com o Anexo V do Tratado de Assunção. Tal Comissão produziu o Protocolo de Harmonização de Normas Sobre Propriedade Intelectual no Mercosul, em Matéria de Marcas, Indicações de Procedência e Denominações de Origem e o Protocolo de Harmonização de Normas em matéria de Desenho Industrial ${ }^{60}$.

Desta forma, visando garantir uma maior proteção aos Direitos de Propriedade Intelectual e dar efetividade a esses direitos no âmbito do MERCOSUL, na decisão 08/95 de 14 de agosto de 1995, o Conselho do Mercado Comum aprovou o Protocolo de Harmonização de Normas sobre Propriedade Intelectual, no tocante aos bens de Propriedade Intelectual.

58 CAMPOS, A. T. A proteção das indicações geográficas nos países do Mercosul, Dissertação (Mestrado Profissional em Propriedade Intelectual e Inovação). Academia de Propriedade Intelectual, Inovação e Desenvolvimento, Coordenação de Programas de Pós-Graduação e Pesquisa INPI, Rio de Janeiro, 2018, p. 45.

59 SOARES, P.B. D. As indicações geográficas e o desenvolvimento territorial no Mercosul: os casos da carne caprina procedente da Região Patagônica e a bovina do Pampa gaúcho da Campanha Meridional do Rio Grande do Sul, Tese (Doutorado em Ciência, Tecnologia e Inovação em Agropecuária) - Universidade Federal Rural do Rio de Janeiro, Rio de Janeiro, 2014.

60 CAMPOS, A. T. A proteção das indicações geográficas nos países do Mercosul, Dissertação (Mestrado Profissional em Propriedade Intelectual e Inovação). Academia de Propriedade Intelectual, Inovação e Desenvolvimento, Coordenação de Programas de Pós-Graduação e Pesquisa INPI, Rio de Janeiro, 2018, p. 47-48. 
PEREIRA, Marta Carolina Gimenez; BOFF, Salete Oro; BRITTO, Emilio Elias Melo de. Internacionalização das indicações geográficas e a sua influência no Mercosul. Revista Eletrônica Direito e Política, Programa de Pós-Graduação Stricto Sensu em Ciência Jurídica da UNIVALI, Itajaí, v.16, n.3, $3^{\circ}$ quadrimestre de 2021. Disponível em: www.univali.br/direitoepolitica - ISSN 1980-7791.

O objetivo do bloco é claro: tentar estabelecer um padrão, no tocante ao tratamento da Propriedade Intelectual, entre os países membros. Tal Protocolo, então, estabeleceu dois princípios, em suas disposições gerais: o do tratamento nacional e o da proteção mínima: "Artigo 1 (Natureza e Alcance das Obrigações): Os Estados Partes garantirão uma proteção efetiva à propriedade intelectual em matéria de marcas, indicações de procedência e denominações de origem, assegurando, no mínimo, a proteção derivada dos princípios e normas enunciados neste Protocolo. Poderão, no entanto, conceder proteção mais ampla, desde que não seja incompatível com as normas e princípios dos Tratados mencionados neste Protocolo. Artigo 3 (Tratamento Nacional): Cada Estado Parte concederá aos nacionais dos demais Estados Partes um tratamento não menos favorável ao que concede a seus próprios nacionais quanto à proteção e exercício dos direitos de propriedade intelectual em matéria de marcas, indicações de procedência e denominações de origem."

Em termos concretos de proteção às Indicações Geográficas, o Protocolo apenas proíbe, em seu art. 20, que "as indicações de procedência e as denominações de origem previstas nos incisos 2 e 3 acima não serão registradas como marcas. Em seu art. 19, por sua vez, dispõe que "os Estados Partes se comprometem a proteger reciprocamente suas indicações de procedência e suas denominações de origem".

No que diz respeito à solução de controvérsias, estas serão resolvidas mediante negociações diplomáticas diretas, no tocante às normas do Protocolo. Em caso de não se chegar a uma solução após as negociações, serão aplicados os procedimentos previstos no sistema de solução de controvérsias, vigente no MERCOSUL.

Já no tocante aos conceitos de Indicações Geográficas, o Protocolo, à semelhança da legislação brasileira, define duas espécies: as indicações de procedência e as denominações de origem (art. 19, incisos 2 e 3): "2) Considera-se indicação de procedência o nome geográfico de país, cidade, região ou localidade de seu território, que seja conhecido como centro de extração, produção ou fabricação de determinado produto ou de prestação de determinado serviço. 3) Considera-se 
PEREIRA, Marta Carolina Gimenez; BOFF, Salete Oro; BRITTO, Emilio Elias Melo de. Internacionalização das indicações geográficas e a sua influência no Mercosul. Revista Eletrônica Direito e Política, Programa de Pós-Graduação Stricto Sensu em Ciência Jurídica da UNIVALI, Itajaí, v.16, n.3, $3^{\circ}$ quadrimestre de 2021. Disponível em: www.univali.br/direitoepolitica - ISSN 1980-7791.

denominação de origem o nome geográfico de país, cidade, região ou localidade de seu território, que designe produtos ou serviços cujas qualidades ou características devam-se exclusiva ou essencialmente ao meio geográfico, incluídos fatores naturais ou humanos."

Superadas essas questões de texto legislativo, o doutrinador Marcos Fabricio Welge Gonçalves ${ }^{61}$ afirma que, apesar da intenção do Protocolo em Harmonizar e proteger as Indicações Geográficas, "o faz de forma fraca" e, ainda, perde "a oportunidade de conciliar-se na forma de estabelecer disposições consoante o ADPIC".

Adicionou, entretanto, a previsão de Indicação Geográfica de Serviço, fato este que não ocorre no Acordo ADPIC (Acordo sobre Aspectos dos Direitos de Propriedade Intelectual Relacionados ao Comércio) ou Acordo TRIPS (Agreement on Trade-Related Aspects of Intellectual Property Rights), que prevê somente para produtos $^{62}$.

O Paraguai aprovou o Protocolo de Harmonização por meio da Lei no 912, de 01 de agosto de 1996, o ratificando em 15 de novembro de 1996, o qual somente entrou em vigor em 06 de agosto de 2000. Já o Uruguai aprovou o Protocolo por meio da Lei no 17052, de 14 de dezembro de 1998, o ratificando em 07 de julho de 2000, que somente entrara em vigor em 06 de agosto de 2000. Nos demais países membros, o citado Protocolo não foi ratificado e, por assim dizer, não entrou em vigor.

Em mais um passo rumo a uma melhor proteção, segurança e simplificação econômica, os Países Membros do MERCOSUL assinaram, na cidade de Bento Gonçalves, no Rio Grande do Sul, a decisão 10/19, em 05 de dezembro de 2019,

61 GONÇALVES, M. F. W. Propriedade Intelectual e a Proteção dos Nomes Geográficos, Juruá, Curitiba, 2018, p. 135.

62 CAMPOS, A. T. A proteção das indicações geográficas nos países do Mercosul, Dissertação (Mestrado Profissional em Propriedade Intelectual e Inovação). Academia de Propriedade Intelectual, Inovação e Desenvolvimento, Coordenação de Programas de Pós-Graduação e Pesquisa INPI, Rio de Janeiro, 2018, p. 49. 
PEREIRA, Marta Carolina Gimenez; BOFF, Salete Oro; BRITTO, Emilio Elias Melo de. Internacionalização das indicações geográficas e a sua influência no Mercosul. Revista Eletrônica Direito e Política, Programa de Pós-Graduação Stricto Sensu em Ciência Jurídica da UNIVALI, Itajaí, v.16, n.3, $3^{\circ}$ quadrimestre de 2021. Disponível em: www.univali.br/direitoepolitica - ISSN 1980-7791.

que configurava o Acordo para a Proteção Mútua das Indicações Geográficas Originárias, nos Territórios dos Estados Partes do Mercado Comum do Sul.

O objetivo geral do Acordo, segundo o seu art. 10, é a "proteção mútua das indicações geográficas originárias nos territórios dos Estados Partes do MERCOSUL, no marco de seus respectivos ordenamentos jurídicos nacionais e dos acordos internacionais multilaterais de que são parte". O art. 10, inciso 2, revela que, após a "realização dos procedimentos de consulta pública e análise técnica ", o "Grupo Mercado Comum (GMC) aprovará, por meio de Resolução, a lista de Indicações Geográficas que serão mutuamente protegidas nos termos do presente Acordo." Assim, cada Estado Membro protegerá as Indicações Geográficas listadas na referida resolução.

Salienta-se que o acordo não protegerá Indicações Geográficas de terceiros países não integrantes do MERCOSUL, que sejam protegidas em algum Estado Membro. Logo, alcançando a proteção apenas às Indicações Geográficas proveniente unicamente dos Estados Membros. E "uma vez reconhecida a Indicação Geográfica, o termo protegido não será considerado "de uso comum" pelos Estados Partes." (art. 30).

O referido acordo mantém a proibição de registro de Indicações Geográficas como Marcas, de acordo com o texto normativo do Protocolo de Harmonização, salvo quando o pedido de registro de marca for anterior à entrada em vigor da referida Resolução do Acordo.

O Acordo inova, ainda, ao criar um Comitê de Indicações Geográficas (art. $8^{\circ}$ ), integrado por representantes das "instituições ou organismos nacionais competentes em matéria de proteção de Indicações Geográficas e dos Ministérios de Relações Exteriores dos Estados Partes, para os quais o presente Acordo se encontre vigente". São funções do comitê:

a) Receber, em suas reuniões, notificações dos Estados Partes sobre novas Indicações Geográficas que foram protegidas domesticamente, com vistas a obter a proteção prevista no presente Acordo nos demais Estados Partes; 
PEREIRA, Marta Carolina Gimenez; BOFF, Salete Oro; BRITTO, Emilio Elias Melo de. Internacionalização das indicações geográficas e a sua influência no Mercosul. Revista Eletrônica Direito e Política, Programa de Pós-Graduação Stricto Sensu em Ciência Jurídica da UNIVALI, Itajaí, v.16, n.3, $3^{\circ}$ quadrimestre de 2021. Disponível em: www.univali.br/direitoepolitica - ISSN 1980-7791.

b) Propor ao GMC, após a realização dos procedimentos indicados no item a), a incorporação de novas Indicações Geográficas à lista que faz referência o artigo 1.2 do presente Acordo;

c) Receber notificações dos Estados Partes caso uma das Indicações Geográficas reconhecidas no MERCOSUL deixe de ser protegida no seu país de origem ou caia em desuso. Recebida essa notificação, o Comitê sugerirá ao GMC a atualização da Lista a que faz referência o artigo 1.2 do presente Acordo;

d) Possibilitar a implementação efetiva do presente Acordo. Ao exercer essa função, o Comitê levará em conta a aplicação harmônica das legislações dos Estados Partes; e Supervisionar a execução e o cumprimento do previsto no presente Acordo, assim como das recomendações originadas no próprio Comitê;

f) Trocar informações sobre os desenvolvimentos legislativos nacionais ou de outra natureza em matéria de Indicações Geográficas"

O novo Acordo notadamente fez mais progressos que o Protocolo de Harmonização, mas ainda não foi ratificações por nenhum dos Países Membros. Um Acordo inteiramente atribuído às Indicações Geográficas já demonstra a importância desse instituto para a economia do bloco. Tal sinaliza também a outros Países e Blocos Econômicos o relevo que se dá a essa matéria no MERCOSUL, o que, por certo, facilitará novos acordos de comércio.

O fato é que as Indicações Geográficas estão se tornando um elemento fundamental no comércio mundial. O MERCOSUL, com bloco econômico de relevância no cenário mundial, precisava sinalizar para o mundo que também está antenado com essa nova tendência. Dessa forma, avançar nas discussões era de fundamental importância, já que o Protocolo de Harmonização tinha patentemente falhando, uma vez que o Brasil e a Argentina tinham sequer o ratificado.

Esse acordo abre novas possibilidades para o Brasil e demais países do Bloco, mas para o bloco como um todo. Blocos como a União Europeia, que valorizam extremamente as Indicações Geográficas, ficaram mais "confortáveis" em assinar acordos de comércio com o MERCOSUL. O que resta, agora, é esperar para avaliar 
PEREIRA, Marta Carolina Gimenez; BOFF, Salete Oro; BRITTO, Emilio Elias Melo de. Internacionalização das indicações geográficas e a sua influência no Mercosul. Revista Eletrônica Direito e Política, Programa de Pós-Graduação Stricto Sensu em Ciência Jurídica da UNIVALI, Itajaí, v.16, n.3, $3^{\circ}$ quadrimestre de 2021. Disponível em: www.univali.br/direitoepolitica - ISSN 1980-7791.

o impacto que a proteção mútua das Indicações Geográficas originárias nos territórios dos Estados Partes do Mercado Comum do Sul irá gerar nos acordos já em discussão e no futuro.

\section{CONSIDERAÇÕES FINAIS}

As Indicações Geográficas são reconhecidas desde há muito tempo, como se vê desde as referências a esse instituto, nos textos bíblicos.

Conforme o tempo foi passando, a importância das Indicações Geográficas foi aumentando e se fez necessário recorrer a tratados multilaterais entre países, e até mesmo blocos econômicos, para que fosse mais bem regulamentado, de modo a evitar atos de concorrencial desleal e falsificação.

O mais importante Acordo Internacional que versou sobre o instituto, o Acordo ADPIC ou TRIPS (Trade-Related Aspects of Intellectual Property Rights), fora assinado, principalmente pelo entendimento de que haveria um aumento, do comércio internacional, se houvesse uma maior proteção dos direitos de Propriedade Intelectual. As previsões desse aumento estão se constatando e, a cada dia, aumentando.

O fator globalização também tem sido determinante para essa nova fase das Indicações Geográficas. Alguns autores, ao contrário de tantos outros, afirmam que a globalização fortalecem os produtos territoriais, os retirando da perspectiva local, projetando-os para o global.

O modelo econômico de arquipélagos, que antes servia ao desenvolvimento tradicional, baseado no produtivismo, já não encontra mais guarida nesse novo momento histórico, que tem a globalização como um dos seus principais elementos.

É o momento de substitui-lo pelo modelo que reagrupa a produção de uma forma que, em um mesmo lugar, possa haver várias funções de produção e não apenas uma (como de "fornecimento de recursos locais pré-existentes", por exemplo), o 
PEREIRA, Marta Carolina Gimenez; BOFF, Salete Oro; BRITTO, Emilio Elias Melo de. Internacionalização das indicações geográficas e a sua influência no Mercosul. Revista Eletrônica Direito e Política, Programa de Pós-Graduação Stricto Sensu em Ciência Jurídica da UNIVALI, Itajaí, v.16, n.3, $3^{\circ}$ quadrimestre de 2021. Disponível em: www.univali.br/direitoepolitica - ISSN 1980-7791.

que valoriza a uma autonomia dos locais. Tal modelo se denomina modelo econômico de mosaico.

Tal modelo alberga perfeitamente as Indicações Geográficas, porque valoriza a produção local, da autonomia aos países e comunidades, já que todas as funções de produção ficam alocadas na região geográfica.

As questões ambientais também se tornam um elemento importante para a substituição do modelo tradicional de desenvolvimento rural. As commodities desse modelo produtivista utilizam tecnologia em larga escala, que alteram a composição original dos alimentos, provocando incertezas com relação à sua qualidade. Desta forma, a alternativa que resta aos consumidores é a procura por alimentos que tenham a sua qualidade e sua procedência atestados.

Nesse contexto é que se insere o referencial teórico da Escola Francesa da Economia da Qualidade Agroalimentar, que deixa de lado a abordagem econômicotecnológica do modelo de desenvolvimento tradicional e passa a abordar a qualidade como construção social, utilizando, para tanto, de conceitos sociais e econômicos.

Desta forma, certificação dos produtos agropecuários se enquadra nesse contexto de indefinições provocadas, dentre outros fatores, pela evolução tecnológica, globalização e mudanças climáticas, porque garante a procedência do produto. As Indicações Geográficas, por sua vez, como uma espécie de certificação, ganha mais relevo nesse cenário.

Por fim, como bem demonstrado, as Indicações Geográficas estão se tornando um elemento fundamental no comércio mundial. O MERCOSUL, objeto de recorte desse trabalho, com bloco econômico de relevância no cenário mundial, precisa sinalizar para o mundo que também está atento a essa nova tendência.

O processo de compreensão da importância das Indicações Geográficas por parte dos Estados Membros do MERCOSUL foi longo e vem desde a assinatura do Tratado de Assunção. Em 2019, o bloco deu essa resposta positiva à comunidade internacional, no tocante à demonstração de que as Indicações Geográficas são 
PEREIRA, Marta Carolina Gimenez; BOFF, Salete Oro; BRITTO, Emilio Elias Melo de. Internacionalização das indicações geográficas e a sua influência no Mercosul. Revista Eletrônica Direito e Política, Programa de Pós-Graduação Stricto Sensu em Ciência Jurídica da UNIVALI, Itajaí, v.16, n.3, $3^{\circ}$ quadrimestre de 2021. Disponível em: www.univali.br/direitoepolitica - ISSN 1980-7791.

elemento fundamental para a economia dos Países Membros e, como tal, deve ser devidamente normatizado. Para tanto, foi assinado o Acordo para a Proteção Mútua das Indicações Geográficas Originárias nos Territórios dos Estados Partes do Mercado Comum do Sul. O mútuo reconhecimento de IGs é a novidade e tem repercussões positivas para o comércio exterior, pois o produto ou serviço passa a ser protegido no país de origem e no outro parceiro, traduzindo-se na facilitação do acesso, da produção, da comercialização e da promoção da pesquisa e desenvolvimento.

\section{REFERÊNCIAS DAS FONTES CITADAS}

ALMEIDA, A. F. R. IG, indicação de proveniência e denominação de origem: os nomes geográficos na propriedade industrial, In: A. M. LEITÃO et al, Direito industrial. vol. I, Coimbra: Almedina, 2001, p. 5-77.

ALMEIDA, A. F. R. A Autonomia Jurídica da Denominação de Origem. Almedina, 2010.

BARBOSA, D. "Propriedade Intelectual no âmbito do Mercosul", 2004, em http://www.denisbarbosa.addr.com/paginas/200/internacional.html.

BARROS, C. E. C. Manual de Propriedade Intelectual. Aracaju: Evocati, 2007.

BÍBLIA, Oséias, 14,7. Disponível em https://www.bibliaonline.com.br/acf. Acesso em setembro 2021.

BOFF, Salete Oro. Desafios da Inovação Tecnológica para a Sustentabilidade Intergeracional. Sequência (UFSC), v. 41, p. 265-287, 2019.

BOFF, Salete Oro. PEREIRA, Marta Carolina Giménez . Conocimientos tradicionales: acercamientos de los marcos regulatorios de propiedad intelectual entre Brasil y México. Revista Opinião Jurídica (Fortaleza), v. 15, p. 198-219, 2017.

BOFF, Salete Oro; FORTES, Vinícius Borges; TOCCHETTO, Gabriel Z. Propriedade Intelectual e Gestão da Inovação-entre Invenção e Inovação. Erechim-RS: Deviant, 2019. v. 1.

BOFF, Salete Oro; FORTES, Vinícius Borges; MENEGAZZO, Andre; TOCCHETTO, Gabriel Z. Propriedade Intelectual - Marcos Regulatórios. Erechim-RS: Deviant, 2017. v. 1. 
PEREIRA, Marta Carolina Gimenez; BOFF, Salete Oro; BRITTO, Emilio Elias Melo de. Internacionalização das indicações geográficas e a sua influência no Mercosul. Revista Eletrônica Direito e Política, Programa de Pós-Graduação Stricto Sensu em Ciência Jurídica da UNIVALI, Itajaí, v.16, n.3, $3^{\circ}$ quadrimestre de 2021. Disponível em: www.univali.br/direitoepolitica - ISSN 1980-7791.

BOFF, Salete Oro; FORTES, Vinícius Borges; MENEGAZZO, Andre; TOCCHETTO, Gabriel Z. Propriedade Intelectual e Gestão da Inovação. Erechim-RS: Deviant, 2017. v. 1. 226p.

BRUCH, K. L. Signos Distintivos de Origem: Entre o Velho e o Novo Mundo Vitivinícola, 2011, 277f, Tese de Doutorado em Direito para obtenção do título de Doutor em Direito no Programa de Pós-Graduação em Direito da Universidade Federal do Rio Grande do Sul e o título de Doutor em Direito na Université Rennes I, 2011, pp. 42 y ss.

BUSCH, L. The Moral economy of grades and standards. Journal of Rural Studies, n. 16, 2000.

BUGALLO, B. La protección jurídica de las indicaciones geograficas en los países del Mercosur In: Anuario de Derecho Comercial, Tomo 9, Montevideo: Fundacion de Cultura Universitaria, 2001.

CAMPOS, A. T. A proteção das indicações geográficas nos países do Mercosul, Dissertação (Mestrado Profissional em Propriedade Intelectual e Inovação), Academia de Propriedade Intelectual, Inovação e Desenvolvimento. INPI, Rio de Janeiro, 2018.

CARVALHO, N. T. P. A estrutura dos sistemas de patentes e de marcas passado, presente e futuro. Rio de Janeiro: Lumem Juris, 2009.

CARNOY et al. The New Global Economy in the Information Age. PA: University Park, 1993.

CASTELLS, M. The information economy and the new international division of labour, In: M.

CERQUEIRA, J. G. Tratado da propriedade intelectual. Rio de Janeiro: Forense, 1946.

DENIS, D. Appellation d'origine et indication de provenance. Paris: Dalloz, 1995.

EYMARD-DUVERNAY, E. La négociation de la qualité. Économie rurale. La qualité dans l'agro-alimentaire, $n^{\circ} 217,1993$.

FRISON-ROCHE, M. A.; PAYET, M. S. Droit de la concurrence. Paris: Dalloz, 2006.

GONÇALVES, M. F. W. Propriedade Intelectual e a Proteção dos Nomes Geográficos. Curitiba: Juruá, 2018.

HARVEY, D. The Condition of Postmodernity. Oxford: Blackwell, 1989. 
PEREIRA, Marta Carolina Gimenez; BOFF, Salete Oro; BRITTO, Emilio Elias Melo de. Internacionalização das indicações geográficas e a sua influência no Mercosul. Revista Eletrônica Direito e Política, Programa de Pós-Graduação Stricto Sensu em Ciência Jurídica da UNIVALI, Itajaí, v.16, n.3, $3^{\circ}$ quadrimestre de 2021. Disponível em: www.univali.br/direitoepolitica - ISSN 1980-7791.

HISRICH, R. D.; PETERS, M. P.; SHEPHERD, D. A. Empreendedorismo. 5. ed. Porto Alegre: Bookman, 2004.

LAGO GIL, R. Las marcas colectivasy las marcas de garantia. 2 ed., Navarra: Civitas, 2006.

LAZZAROTTO, N. F. Estudos sobre o mercado de certificações de qualidade em alimentos no Brasil. Seminários de Administração, 5, FEA/USP, São Paulo, 2001.

MAILLAT, D. Globalização, meio inovador e sistemas territoriais de produção. Revista Internacional de Desenvolvimento Local, Vol. 3, N. 4, p. 9-16, mar. 2002.

NASSAR, A. M. Certificação no agronegócio - Estudo temático. IX Seminário Internacional PENSA de Agribusiness, Águas de São Pedro, 1999,

NAVARRO, Z. Desenvolvimento rural no Brasil - os limites do passado e os caminhos do futuro, Estudos Avançados, vol.15, no 43, set./dez 2011.

NIEDERLE, P.A. Delimitando as fronteiras entre mercados convencionais e alternativos para a agricultura familiar, Revista de Extensão Rural, DEAER/PPGEXR - CCR - UFSM, Ano XVI, no 18, Jul/2009, pp. 6-7.

OCDE, Economies locales et globalisation, Paris, 1995.

PERRIN, J. C. La reconversion du Bassin d'Alès, CER, Aixen-Provence, 1983.

PORTO, C. R. Indicações Geográficas: a proteção adequada deste instituto visando o interesse público nacional. Monografia (Pós-graduação em Direito). Faculdade de Direito, Universidade Federal do Rio de Janeiro, Rio de Janeiro, 2007, p. 17;

REIS, L. L. M. REIS. Indicação Geográfica no Brasil: determinantes, limites e possibilidades, Salvador, 2015, 270 f, Tese (Doutorado) - Universidade Federal da Bahia. Instituto de Geociências, 2015, p. 32.

SATO G. S.; BRITO, P. R. B. "A Relevância da Economia da Qualidade Agroalimentar no Contexto Atual", 2007, em http://www.iea.sp.gov.br/out/TerTexto.php?codTexto $=8944$.

SCOTT, A. High Technology and Territorial Developpment: the Rise of the Orange County Complex, Urban Geography, n. 7, p. 3-45, 1986.

SOARES, P. B. D. As indicações geográficas e o desenvolvimento territorial no Mercosul: os casos da carne caprina procedente da Região Patagônica e a bovina do Pampa gaúcho da Campanha Meridional do Rio Grande do Sul, Tese 
PEREIRA, Marta Carolina Gimenez; BOFF, Salete Oro; BRITTO, Emilio Elias Melo de. Internacionalização das indicações geográficas e a sua influência no Mercosul. Revista Eletrônica Direito e Política, Programa de Pós-Graduação Stricto Sensu em Ciência Jurídica da UNIVALI, Itajaí, v.16, n.3, $3^{\circ}$ quadrimestre de 2021. Disponível em: www.univali.br/direitoepolitica - ISSN 1980-7791.

(Doutorado em Ciência, Tecnologia e Inovação em Agropecuária) - Universidade Federal Rural do Rio de Janeiro, Rio de Janeiro, 2014.

STAUDT; SATO; PITHAN E SILVA; VARELA; CHALITA. , Processo de certificação de qualidade para produtos agroalimentares: o selo produto, Informações Econômicas, v.39, n.3, São Paulo, mar. 2009, p. 69.

VARELLA, M. D. Propriedade intelectual de setores emergentes. São Paulo: Atlas, 1996.

VIDAL, M. Historie de la vigne et des vins dans le monde. Bordeaux: Féret, 2001.

VELTZ, P. Mondialisation, villes et territoires : l'économie d'archipel. Paris: Presses Universitaires de France, 2005. 